\title{
FENS REPORT
}

\section{NUTRITION, DIETETICS AND FOOD SCIENCES DEGREES ACROSS EUROPE}

Cuervo $\mathrm{M}^{1}$, Brehme $\mathrm{U}^{2}$, Egli $\mathrm{IM}^{2}$, Elmadfa $\mathrm{I}^{2}$, Gronowska-Senger $\mathrm{A}^{2}$, Tetens $\mathrm{I}^{2}$, Martínez $\mathrm{JA}^{1,2^{\star}}$, Branca $\mathrm{F}^{2^{\star \star}}$.

${ }^{1}$ Department of Physiology and Nutrition, University of Navarra, Pamplona, Spain.

${ }^{2}$ Federation of European Nutrition Societies (FENS)

${ }^{*}$ FENS Secretary and ${ }^{\star *}$ FENS President. All other contributors are members of nationally representative European Societies.

Key words:

Bologna Declaration, Nutrition and Dietetics, Food sciences, Training and competences, Europe, Higher Education System 


\section{Background}

Nutrition and food quality are factors contributing to health maintenance and promotion as well as for therapeutical purposes. From a few decades ago, this assertion has become more important not only for the scientific community, but also among consumers, who demand healthy, safe and nutritious foods, even with additional beneficial properties beyond the nutritional value.

Latest advances in this multidisciplinary field concerning foods and nutrition are forcing European policy-makers and academic boards to adapt and update the current teaching programmes concerning nutrition- and food-related sciences in order to be prepared to fit into the European Space for Higher Education system. This situation provides a unique opportunity for a renewed analysis in order to achieve an agreement for a regulated education in this area, that currently involve general practitioners, physicians, paediatricians, pharmacists, nurses, food scientists, chemical engineers and, of course, dieticians and nutritionists. For all these reasons, policy-makers, officers and civil servants from all European countries together with higher education institutions, academic authorities, scientific societies and professional organizations should make a great effort of integration and collaboration.

In this context, the nutrition and dietetics practice across Europe as well as food sciences implementation are, nowadays, diverse and have evolved to meet the needs of the users, patients and consumer demands within each country. The qualification is nationally regulated in some European countries, but often it is not comparable across Europe. The titles are only differentiated in a minority of countries. Comparable qualifications within the EU would then support the European labour market, enabling nutritionists, dieticians and other food, health or social professionals to study and work more easily and comfortably throughout the European Union in Food and Nutrition issues.

Within Europe, nutritionists, dieticians and food scientists find themselves practising in the following main areas: administrative, clinical, public health or community, marketing and research. Administrative positions are those focused primarily within food service management with responsibility for providing nutritionally adequate, quality food to individuals or groups of healthy or diseased, living in an institution or a community setting. Clinical professionals are those who have duties for planning, education, supervision and evaluation of a clinically devised eating plan to restore the patient to functional nutritional health, who can work in primary care as well as health institutions. Public health or community nutritionists/dieticians and food-related professionals are directly involved in health promotion and policy formulation that leads to the promotion of healthy food choices amongst individuals and groups to improve or maintain their nutritional health and minimizes risk from nutritionally derived origin. Marketing nutritionists/dieticians as well as food professionals advice about innovation and new products, close to social marketing concerning food issues. Finally, a researcher 
in the area of nutrition and food is able to join in a multidisciplinary team of research to develop original studies about new products and nutrition and health-interactive issues.

Nutritionists and food-related professionals, regardless of their background, must be able to interpret and communicate nutritional knowledge to groups and individuals. Degree holders in these areas must be able to elicit information on nutritional requirements and research from the various disciplines in order to produce practical advice on food intake and associated counselling resources. These professionals are required to work on a multidisciplinary team within the complex frameworks of ethical and legal boundaries at workplace (i.e. health services, private practice, food companies and manufacturers, industry, local government, education or research). In some European countries, the practice of dietetics is restricted to dieticians who have been overseen by a regulatory body. There are two pre-registration routes concerning dietetics professional development that take place in higher education. A first university cycle qualification is the most popular route to gain a qualification and registration in dietetics. However, it is possible for individuals with a Bachelor's degree in an appropriate subject (normally in human sciences) to undertake a second programme suitably constructed and delivered to achieve a dietetics qualification and registration. A number of Master's degrees and postgraduate courses are being developed to fulfil these criteria at European level, although a regulated implementation is required under the Bologna Declaration concerning university higher education in Europe.

\section{Training and competences}

Nutrition and food sciences are closely related with health and have autonomous capacity as multidisciplinary sciences. Education programmes must promote an integrative approach concerning the application of theory into practice. Therefore, nutrition and food sciences studies and degrees must be designed to provide learning opportunities that facilitate the acquisition of professional capabilities in addition to a solid academic background.

The practical part of the education programmes is an essential element of any qualification leading to qualification in nutrition, dietetics or food sciences. In some countries the practice of dietetics is restricted to dieticians who have undergone a recognised education and training. The practical programme includes skills to demonstrate capabilities in the academic components and at workplace or practical component. This practical component must allow demonstration of the application of theory in the practical setting.

A theoretical programme in nutrition, dietetics and food-related sciences require formation and training on the following areas:

- Basic Sciences: physics, chemistry, biochemistry, biology, genetic, anatomy, histology, physiology, mathematics, statistics, research methods and computers skills 
- Food and nutrition sciences: food science, nutrition, dietetics, clinical medicine, pharmacology, microbiology, immunology, food skills, sensory evaluation, nutritional assessment, food safety and food hygiene

- Food service sdministration: management and leadership, administration, healthcare organisation, food planning and production, catering and food service, legislation, economics, equipment, purchasing, marketing and community services.

- $\quad$ Nutrition education and community nutrition: public health, health promotion, ethics, sociology and social policy, psychology, enquiry, teaching methods, education and communication, food culture and epidemiology.

Professionals with nutritional or food sciences-related backgrounds must be ready to work in a multidisciplinary team in the benefit of the society, including all aspects of the food chain according to the consumer/patient demands. Therefore, physicians, paediatricians, pharmacists, nurses, social workers, chemical engineers and so on, in addition to nutritionist, should be integrated for a focused action with a perspective of sharing knowledge and skills of highest standards in the future.

\section{General References}

- Agencia Nacional de Evaluación de la Calidad y Acreditación. Informe de la Comisión Evaluadora del Proyecto de Titulación en Ciencia y Tecnología de los Alimentos/Nutrición Humana y Dietética. Madrid, 2005. http://www.aneca.es/modal eval/docs/libroblanco jun05 nutricion.pdf

- Änderung des Studienplanes für das Diplomstudium der Ernährungswissenschaften an der Formal- und Naturwissenschaftlichen Fakultät der Universität Wien gemäß Universitäts-Studiengesetz Erschienen im Mitteilungsblatt der Universität, Stück XII, Nummer 43, am 16.09.1997, im Studienjahr 1996/97

- Confederation of EU Rectors' Conferences and the Association of European Universities (CRE). The Bologna Declaration on the European Space Higher Education. 1999. http://europa.eu.int/comm/education/policies/educ/bologna/bologna.pdf

- Curriculum für das Bakkalaureatsstudium Ernährungswissenschaften, Mitteilungsblatt der Universität Studienjahr 2005/2006 - Ausgegeben am 02.06.2006 - 32. Stück

- Deen D. How can nutrition education contribute to competency-based resident evaluation? Am J Clin Nutr 2006;83:976S-980S.

- ECTS -The Future European Credit Transfer and Accumulation System. 2006 http://europa.eu.int/comm/education/programmes/socrates/ects_en.html

- $\quad$ European Academic and Practitioner Standards For Dietetics. European Federations of the Associations of Dieticians. 2005. http://www.efad.org/Reports/EFAD_BenchmarkJune2005_UK.pdf

- González J, Wagenaar R,. Tuning Educational Structures in Europe. 2005. http://tuning.unideusto.org/tuningeu/

- Hark LA. Lessons learned from nutrition curricular enhancements. Am J Clin Nutr 2006;83:968S-970S.

- Nutrition Society. Voluntary register. Continuing Professional Development Scheme. 2005. http://www.nutritionsociety.org/index

- Rodriguez MC, Larralde J, Martinez JA. Computer-assisted instruction in nutrition: a creative tool for medical education. Med Educ 1997 ;31:229-231.

- Widhalm K, Miranda-da-Cruz B, Pokorny J, Tetens I, Virtanen SM, Lemonnier D, Oberritter H, Trichopoulou A, McKenna B, Brattistini N, Berge S, Gronowska-Senger A, Vaz de Almeida MD, Correa F, Olmedilla B, Ellegard LH, Keller U, Vries PJF, Edwards CA. Federation of European Nutrition Societies. FENS Program for nutrition education in medical schools. Ann Nutr Metab 1999;43:66-68. 

Table 1. Current Situation in Europe (2007)

\begin{tabular}{|c|c|c|c|c|c|c|}
\hline \multirow[t]{2}{*}{ Country } & \multirow{2}{*}{$\begin{array}{l}\text { No Univ } \\
\text { NHD/ } \\
\text { CTA }\end{array}$} & \multicolumn{2}{|l|}{ Model / years } & \multirow{2}{*}{$\begin{array}{l}\text { Access to } \\
\text { PhD } \\
\text { NHD/CTA }\end{array}$} & \multirow[t]{2}{*}{ Title (NHD) in mother tongue } & \multirow{2}{*}{$\begin{array}{l}\text { National } \\
\text { Registration } \\
\text { NHD }\end{array}$} \\
\hline & & NHD & CTA & & & \\
\hline Austria & $6 / 1$ & $\begin{array}{l}\text { Dipl./5 } \\
\text { BSc/3 } \\
\mathrm{MSc} / 2\end{array}$ & $\begin{array}{l}\mathrm{BSc} / 3 \\
\mathrm{MSc} / 2\end{array}$ & Yes/ & $\begin{array}{l}\text { Mag. rer. nat. Ernährungswissenschaften } \\
\text { (MSc Nutritional Sciences) } \\
\text { BSc Ernährungswissenschaften } \\
\text { MSc Natural Sciences (Nutritional Sciences) } \\
\text { mit Spezialisierung in Molekulare Ernährung, } \\
\text { Food Quality and Food Safety, } \\
\text { Ernährungsepidemiologie, Public Health } \\
\text { Nutrition } \\
\text { BSc Lebensmittel- und Biotechnologie } \\
\text { (Agricultural University) } \\
\text { MSc Lebensmittelwissenschaften und - } \\
\text { technologie (Agricultural University) } \\
\text { MSc Safety in the Food Chain (Agricultural } \\
\text { University) } \\
\text { BSc Dietetics }\end{array}$ & Yes \\
\hline Belgium & $2 / 3$ & $\begin{array}{l}\text { Non-BSc/3 } \\
\text { BSc/3 }\end{array}$ & $\begin{array}{l}\mathrm{BSc} / 3 \\
\mathrm{Post} / 2\end{array}$ & & BSc diététique & No \\
\hline Denmark & $3 / 1$ & $\mathrm{BSc} / 3,5$ & $\begin{array}{l}\mathrm{BSc} / 3 \\
\mathrm{MSc} / 2\end{array}$ & Yes/ & BSc Nutrition and Health & Yes (clinic) \\
\hline Finland & $1 / 1$ & $\mathrm{MSc} / 5$ & $\begin{array}{l}\mathrm{BSc} / 3-4 \\
\mathrm{MSc} / 1,5\end{array}$ & Yes/ & MSc Health Sciences & Yes \\
\hline France & $26 / 36$ & Non-BSc/2 & $3-5$ & & $\begin{array}{l}\text { DUT Genie Biologique-option dietétique } \\
\text { BTS en dietétique }\end{array}$ & Yes \\
\hline Germany & $16 / 0$ & $\begin{array}{l}\text { Dipl./3,5-4,5 } \\
\text { BSc 3-3,5 } \\
\text { MSc 1,5-2 }\end{array}$ & $\begin{array}{l}\text { Yes } \\
\text { No* } \\
\text { Yes }\end{array}$ & & $\begin{array}{l}\text { Diplom-Oecotrophologe } \\
\text { Diplom-Ernährungswissenschaftler } \\
\text { Diplom-Oecotrophologe (FH) } \\
\text { BSc Oecotrophologie } \\
\text { BSc Ökotrophologie } \\
\text { BSc Ernährungswissenschaft } \\
\text { BSc Ernährung und Lebensmittel } \\
\text { MSc Ökotrophologie } \\
\text { MSc Ernährungswissenschaft } \\
\text { MSc Ernährungswissenschaften } \\
\text { MSc Food Science } \\
\text { Diplom-Ingenieur } \\
\text { Versorgungsmanagement (FH) } \\
\text { Diätassistent (Non-BSc) }\end{array}$ & \\
\hline Netherlands & $3 / 1$ & $\begin{array}{l}\mathrm{BSc} / 4 \\
\mathrm{MSc} i ?\end{array}$ & $\mathrm{BSc} / 3$ & Yes/ & $\begin{array}{l}\text { BSc dietist } \\
\text { BSc voedinskundige } \\
\text { BSc/MSc Human Nutrition and Dietetics }\end{array}$ & Yes \\
\hline Ireland & $2 / 4$ & $\begin{array}{l}\mathrm{HD} / 2 \\
\mathrm{BSc} / 3-4 \\
\mathrm{MSc} / 1-2\end{array}$ & $\begin{array}{l}\text { BSc/4 } \\
\text { Post/2 }\end{array}$ & YES/NO & BSc (Hons) Human Nutrition and Dietetics & Yes \\
\hline Italy & $0 / 8$ & $\begin{array}{l}\mathrm{C} / 3 \\
\text { Laurea/3 }\end{array}$ & $\begin{array}{l}\mathrm{BSc} / 2-5 \\
\mathrm{Post} / 2\end{array}$ & & Laurea in Dietistica & Yes \\
\hline Norway & $0 / 1$ & - & $\begin{array}{l}\mathrm{BSc} / 3 \\
\mathrm{MSc} / 2\end{array}$ & & ( & - \\
\hline Polland & 5 & - & $\begin{array}{l}\mathrm{BSc} / 3-4 \\
\mathrm{MSc} / 1,5\end{array}$ & & $\begin{array}{l}\text { Inzynier or Magister technologii zywnosci i } \\
\text { zywienia }\end{array}$ & - \\
\hline Portugal & $0 / 6$ & $\begin{array}{l}\mathrm{BSc} / 4 \\
\mathrm{Lic} / 4-5\end{array}$ & $\begin{array}{l}\text { Lic. } 2-5 \\
\text { BSc/4 } \\
\text { Post/2 }\end{array}$ & Yes/ & Licenciado en Ciencias da Nutriçao/Dietetica & No \\
\hline Romania & $0 / 1$ & - & $\mathrm{HD} / 5$ & & - & - \\
\hline Slovaquia & $0 / 1$ & - & $\begin{array}{l}\mathrm{BSc} / 3 \\
\mathrm{MSc} / 2\end{array}$ & & - & - \\
\hline Slovenia & $0 / 1$ & - & $\mathrm{HD} / 4,5$ & & - & - \\
\hline Spain & $17 / 22$ & Diplom/3 & $\mathrm{Lic} / 5$ & No/Yes & $\begin{array}{lll}\text { Dietista-Nutricionista/ } & \text { Tecnólogo de } \\
\text { Alimentos } & & \\
\end{array}$ & No \\
\hline Sweden & $4 / 3$ & $\mathrm{BSc} / 4$ & $\begin{array}{l}\mathrm{BSc} / 3 \\
\mathrm{MSc} / 1\end{array}$ & Yes/- & $\begin{array}{l}\text { BSc and MSc Dietetics } \\
\text { BSc and MSc Nutrition } \\
\text { BSc Food Sciences }\end{array}$ & Yes \\
\hline Switzerland & $3 / 1$ & Dipl/3 & $\begin{array}{l}\text { MSc } \\
\text { degree/5 }\end{array}$ & No / Yes & $\begin{array}{l}\text { Dipl. Ernährungsberater(in) or } \\
\text { Diététicien(ne) diplômé(e) }\end{array}$ & Yes \\
\hline $\begin{array}{l}\text { The Czech } \\
\text { Republic }\end{array}$ & $0 / 1$ & - & $\begin{array}{l}\mathrm{BSc} / 3 \\
\mathrm{MSc} / 3\end{array}$ & & - & - \\
\hline U.K & $13 / 6$ & $\begin{array}{l}\mathrm{BSc} / 3-4 \\
\mathrm{MSc} / 2-3\end{array}$ & $\mathrm{BSc} / 3-4$ & YES/NO & BSc (Hons) Human Nutrition and Dietetics & Yes \\
\hline
\end{tabular}

* possible in some cases (assessment of aptitude required)

NHD: Human Nutrition and Dietetics; BSc: Bachelor; CTA: Food Sciences Degrees; MSc: Master; HD: Higher Diploma; POST: Postgraduate; Dipl: Diploma; C: Course; Non-BSc: Non Bachelor. 